\title{
Trust in Management and Work Satisfaction as Predictor of Workplace Deviance in SMEs of Malaysia
}

\author{
Ali Abbasi, \\ Azman Hashim International Business School, University Technology Malaysia, \\ E-mail of corresponding author 1: aliabbasi5555@gmail.com \\ Wan Khairuzzaman Wan Ismail \\ Sulaiman AlRajhi School of Business \\ E-mail of corresponding author 2: mwkhair@jcba.edu.sa \\ Fatemeh Baradari \\ Faculty of Engineering and built Environment, University Kebangsaan Malaysia \\ E-mail of corresponding author 3: Termeh.brd@gmail.com \\ Javad Shahreki \\ Faculty of Business, Multimedia University, Malaysia \\ E-mail of corresponding author 4: Javad.shahreki@mmu.edu.my
}

\begin{abstract}
Deviant workplace behavior has become a most costly phenomenon as it includes a wide range of negative acts performed by the employees to harm the organization and its members. The workplace is a forum where employees are seen behaving in different productive manners in order to achieve a common goal. In this research employee deviant has been conceptualized as destructive. While deviant behavior may be harmful, employee deviance can be constructive and functional as well. Employees who engage in constructive deviance, such as innovative behaviors, can provide organizations with necessary creativity. Past researchers have consistently found correlations between deviant behaviors and employees' evaluations of the quality of their work environment. This study explains the impact of trust in management and work Satisfaction a predictor of workplace deviance. To analyze this preference, the questionnaires were distributed randomly to the employees from different industries in SMEs of Malaysia. From the 150 online questionnaires, 115 responses were received. The result of this study helps the managers and supervisors in monitoring the employees to find any dissatisfaction and precaution against unfairness among labors. This research gives an insight of the type of trust in organization that is salient for each construct and allows the management of organizations to take appropriate actions to improve conditions at the workplace and prevent deviance in the organization, the management must create environment that employee perceive enough care and support. Some organizations need to change the work environment and educate workers on how to adapt and cope better to the workplace. The scope of this study is more concerned about deviance in the workplace and most of the questionnaires were filled by employees of SMEs in Malaysia. The respondents include all employees who work in Malaysia. This research have several funding such as trust in management have positive effects on work Satisfaction and negative effect on workplace deviance, and work satisfaction performed as a mediating role to relationship between trust in management and workplace deviance.
\end{abstract}

Keywords: workplace deviance, trust in management, work satisfaction

DOI: $10.7176 / \mathrm{EJBM} / 12-21-20$

Publication date:July $31^{\text {st }} 2020$

\section{Introduction}

The workplace is a forum where employees are seen behaving in different productive manners in order to achieve a common goal. As people spend a lot of time interacting with each other at the workplace, some of the employee behaviors are unpredictable. That is why managing the behavior of employees is a major concern of authorities. Thus, the organizations wish to have employees who do not bring harm to the workplace but instead carry out tasks, duties, and responsibilities of their position. Such behavior that causes harm to the organization is undesirable and is considered to be deviant. In today's business, deviance is as one of the most serious problems facing organizations. The efficiency of employees and performance of them in the workplace in such a competitive global economy and businesses require some factors that enhance the performance and work satisfaction of employees in the workplace (Alias \& Rasdi, 2015).

The diversity of deviance and numerous causes that lead to dysfunction in the workplace make this issue one of the vital topics in organizational behavior. The relationship and impact of, work satisfaction and workplace 
deviance were explored individually by numerous researchers (Colquitt, Conlon, Wesson, Porter, \& Ng, 2001). Workplace deviance is considered as one of the most costly behaviors against the productivity and efficiency of employee in the workplace. Studies in deviance in the workplace began approximately three decades ago. In these thirty years, plenty of research was conducted on deviance behavior in an organization, which introduced numerous components and a variety of outcomes (Bennett \& Robinson, 2003).

Many organizations recognize the impact of deviance on their outcomes and understand that minimizing workplace deviance is necessary for them to remain competitive in the market. The efficiency of an organization and maximum outcomes of employees in a workplace in such a competitive market requires some factors that impact the enhancement of the performance and job satisfaction of employees in the workplace (Abbasi \& Wan Ismail, 2018). In practical perspective, since WDB covers a wide range of organizational cost, recognition of WDB is vital in each organization to increase efficiency of organization (S. J. Kim \& Chung, 2019). By increasing trust and satisfaction in organizations, those employees who are prone to deviance in organization would decrease (Qi, Liu, \& Mao, 2020). In other words, many components of dysfunctional and other sort of deviance would minimize in the workplace. One of the latest research declared that deviance in workplace considered as one of the vital factor against the productivity of organization (Abbasi, Baradari, Sheghariji, \& Shahreki, 2020). Thus this research attempts to explore the predictors of workplace deviance

\section{Theory and Hypotheses}

Social exchange theory explained that social behavior is the result of an exchange process. The purpose of this exchange is to maximize benefits and minimize costs. This theory highlighted the motivation for behavior and attitudes exchanged among employees to supervisors, colleagues, organizations and teams (Shore et al., 2009). Social exchange theory predicts that individuals who perceive that they are receiving unfavorable treatment are more likely to feel angry, vengeful, and dissatisfied. Consistent with the norms of reciprocity, when individuals are dissatisfied with the organization or their boss, they may reciprocate with negative work behaviors such as withholding effort, arriving late at work, taking longer break times and leaving early. All of these are examples of deviant behavior directed at the organization. Alternatively, the individual may exchange their dissatisfaction with coworkers by engaging in counterproductive behaviors directed at them, such as playing mean pranks, cursing at them, or even sabotaging their work. Some researchers suggest that social exchange theory offers the best explanation for an employee participating and employee's standard of fairness in the organization (Pierce \& Maurer, 2009).

\subsection{Typology of Deviance}

Some researchers like Bennett and Robinson (1995) divided the deviance in two groups. The first one, organizational deviance, is more concerned about direct behavior in organizations which consists of picking up the product or tolls, intentionally damage or disrupt the equipment in the organization, strong reaction to any unpleasant action deviance. The second one, interpersonal deviance, which is related to employee of an organization, comprises of verbal abuse, mobbing and sexual harassment and jeopardizing the colleagues.

Robinson and Bennett (1995) define destructive deviance as an intentional behavior that violates significant organizational norms, thus threatening the wellbeing of an organization, its members, or both. Vardi and Weiner (1996) refine the definition by stipulating that the concept refers to behaviors causing harm or having the potential of causing harm that violate societal norms of proper conduct as well. This behavior can be divided into two main categories according to its objective: behaviors that are directed towards other individuals and those that are directed towards the organization.

The first category, interpersonal destructive deviance, comprises behaviors such as harassing other employees, stealing from other employees and informing on them. The second, organizational destructive deviance, comprises behaviors such as stealing from the company and sabotaging equipment. Most of the studies on negative deviant workplace behavior prior to 1995 were mostly concerned with isolated attempts to answer specific questions about specific deviant acts such as theft, sexual harassment and unethical decision making. Robinson and Bennett (1995) integrated the various deviant workplace behaviors into a single framework in order to gather the increasingly scattered research available on the subject into one comprehensive chart.

In numerous studies on counterproductive behavior, findings show that interpersonal differences play an important role in revealing destructive deviant behaviors in the workplace. For example, Fox and Spector (1999) found a significant correlation between characteristics of locus of control, anxiety characteristics and anger with self-reports on counterproductive behaviors.

Based on Robinson., (1995) A typology was derived of workplace deviance which is based on a twodimensional configuration. On one axis is the target of the deviance which is the organizational-interpersonal dimension. The first dimension of Robinson's typology is the organizational-interpersonal dimension. It ranges from deviance directed at members of the organization (interpersonal) to deviance directed towards the organization itself (e.g. theft). The second dimension of the typology represented the severity of the workplace 
deviance, varying from minor to serious. The severity of the deviance and whether the deviance is intended to harm an individual or the organization as a whole. They then labeled the four quadrants formed by these dimensions production deviance, property deviance, political deviance, and personal aggression.

\subsubsection{Production Deviance}

Production deviance are behaviors that violate the formally proscribed norms delineating the minimal quality and quantity of work to be accomplished. Production deviance refers to behaviors that directly interfere with work being performed in the organization. Production deviance is concerned with the violating employee behaviors that affect the quantity and quality of work in the organization resulting in reduced efficiency while property deviance refers to the misuse or damage of the organization's assets or tangible property (Hollinger \& Clark, 1983).

This research indicates that in terms of reducing absenteeism or tardiness, it does not really matter if your employees love or hate their jobs; what matters is if they love or hate their organization. If managers reduce frustrations in their organization by streamlining processes and making resources available, incidents of unexplained absences and tardiness may decrease. Additionally, the employees' perceptions of the fairness of the organization will impact absences (Everton, Jolton, \& Mastrangelo, 2007).

\subsubsection{Property Deviance}

Property deviance describe those instances where employees acquire or damage the tangible property or assets. Behaviors in the property deviance quadrant are those that are harmful to the organization and are relatively severe. Sabotaging equipment, accepting kickbacks, lying about hours worked, releasing confidential information, intentional errors, misusing expense accounts, and stealing from the company are forms of property deviance. Some of these acts are connected with direct costs for the organization since equipment has to be replaced. Furthermore they can have consequences for productivity because work cannot be performed until the equipment is replaced.-As an example of an employee property deviance behavior one survey found that 75 per cent of employees admitted taking property from an employer at least once (Bennett \& Robinson, 2000).

\subsubsection{Political Deviance}

Political deviance refers to milder interpersonal harmful behavior. The last quadrant, personal aggression, is more harmful interpersonal behavior Cortina (2001) show that 71 percent of the workers were victims of bad manners in the workplace in the last five years. The outcome of employees and the job satisfaction are decreased and the work environment had more stress. In addition, resignation from the organization increased. Aquino, Tripp and Bies (2001) show that most uncivil behavior occurs in the hierarchy of organization, and generally the victims have low level in the organization. There is plenty of research that confirms that deviance in the workplace has a negative effect on the efficiency of the organization (Bourke, 1994). The additional cost of deviance imposed on the organization include the losses of capital through equipment sabotage and compensation payment for an injury which ultimately leads to loss in organization with lower the productivity level.

\subsubsection{Personal Aggression}

Aggression is often understood as physical or something you can see and feel such as grabbing, shoving, or punching. However, the research tells you that there are commonly discussed forms of workplace aggression, such as physical abuse or sexual harassment, but there are many other ways that aggression can be displayed. For instance, people who use the silent treatment, such as ignoring you when they are upset, are using a form of aggression known as passive aggression. Passive aggression can also be exhibited by an employee who shows up late to every meeting because they want to cause a disruption. When someone behaves passive aggressively they are trying to harm a person or the company through non-physical and non-verbal means. Of course there is more than passive aggressiveness and you can find a wealth of information on verbal aggression like sexual harassment (Robinson and Bennett's, 1995). Figure 1.1 illustrates the varieties of deviance in the organization. 


\section{ORGANISATIONAL}

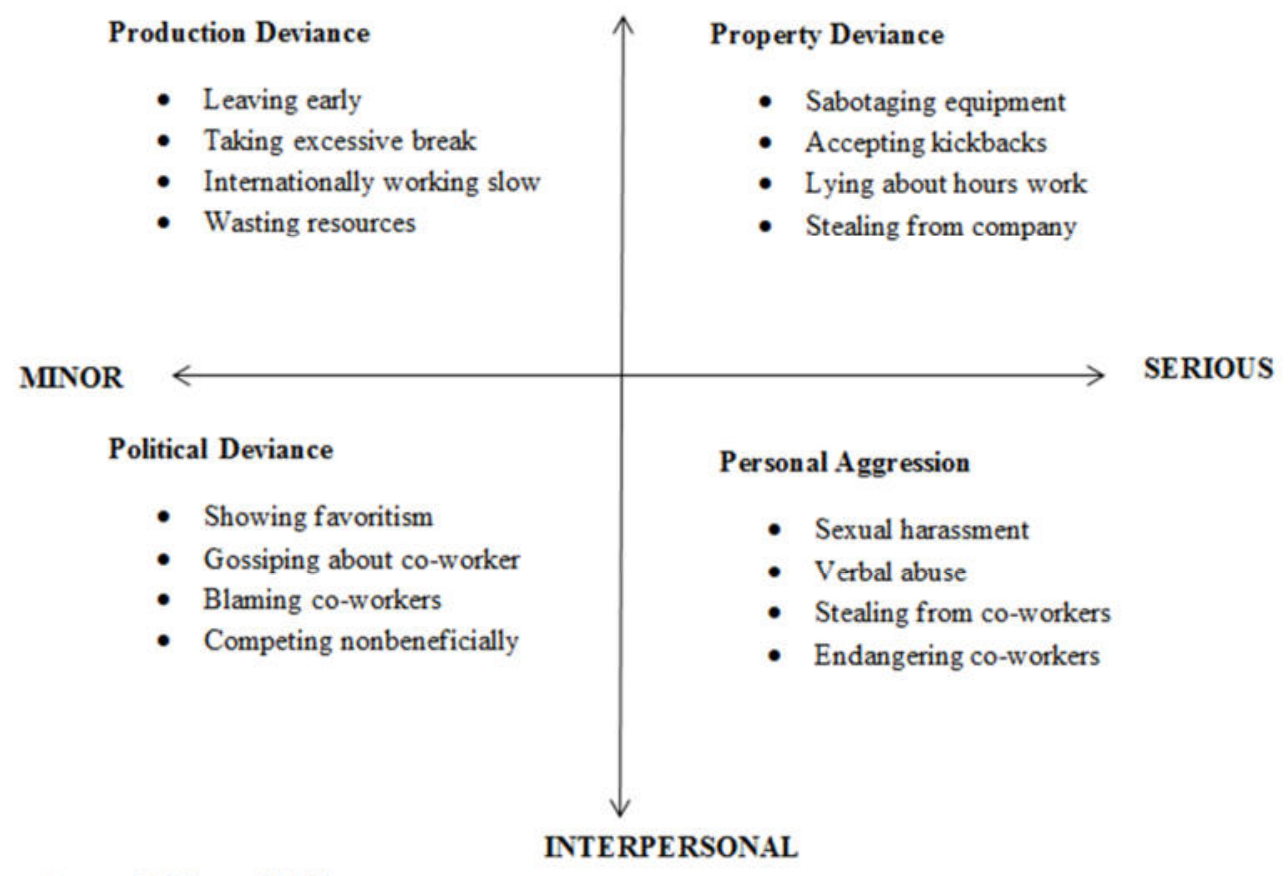

Source: Robinson (1995)

Figure 1.1: Type of deviance

\subsection{Trust in Management and Work Satisfaction}

The level of positive emotional orientation that each organizations' member have in the direction of their occupation in the organization is termed as job satisfaction. Simply we can say, job satisfaction is described as the overall perception of that an individual has towards his or her job (Lee \& Chang, 2008). Individual collation of actual outcome with outcome that was expected by employee based on their perception of the effort they put in their jobs (Cranny, Smith, \& Stone, 1992).

Employee personality has an influence on the work environment in organization and work satisfaction as an important factor impress directly on behavior (Dormann \& Zapf, 2001). Additionally the environment of the workplace has direct relation with the level of employee's job satisfaction. Furthermore, (Ganzach, 1998) also showed that the relationship between work satisfaction, quality of employees and employer relationship is positive.

Most of the time, expectation of employee is linked to satisfaction in their workplace and the role of reward is influence to work satisfaction (Wharton, Rotolo, \& Bird, 2000). The level of work satisfaction is vital in some organizations in which managers accept the responsibility to recruit some professional employees and are determined to maximize job satisfaction among these professional employees. Gill extrapolates the level of trust and level of job satisfaction in the hospitality industry. He proved that work satisfaction of the employee is the principle of efficiency in this industry, because they have direct communication with customers and any dissatisfaction can affect their services to the customer (Gill, 2008).

Work satisfaction is a positive feeling about one's job resulting from an evaluation of its characteristics. There is a fact that an employee's job is more than just the obvious activities of shuffling paper, writing programming code or working with big machines in a factory or many others. Some research result exposed that employee perceptions of trust in organizational HR practices that signal investment in employees and recognition of their contributions to the development of support. In order to understand the relationship between trust in management and work satisfaction, it is vital to consider how employees can be vulnerable to management, and how vulnerability relates to performance. If the manager uses the information, either intentionally or unintentionally, in a way that damages the employee's interests, the outcome for the employee is negative. Propose that such negative outcomes will lead the employee to reevaluate the manager's trustworthiness, and subsequently be less willing to be vulnerable to the manager at a later point in time (Mayer, Davis, \& Schoorman, 1995).

Further, the impact of trust on the turnover employees highlighted. also suggest that perceived organizational support is positively related to satisfaction of employees, which in turn are negatively related to deviance. This sequence is consistent with contemporary turnover process models and research (Allen, Shore, \& Griffeth, 2003). 
Hence, the reviews of the above literature that highlight and rely on social exchange theory, trust on management have an impact on work satisfaction; therefore, the following hypothesis are proposed;

Hypothesis1: There is a positive relationship between trust in management and work satisfaction.

\subsection{Work Satisfaction and Workplace Deviance}

The degree to which members of an organization have a positive affective orientation toward their job in the organization is termed as work satisfaction. In simple words, work satisfaction is defined as the general approach of a person towards his job (Lee \& Chang, 2008). work satisfaction can be defined as a pleasurable or positive emotional state resulting from the appraisal of one's job or job experiences (Judge, Thoresen, Bono, \& Patton, 2001). From a conceptual perspective and based on inductive reasoning, it follows that individuals who have a negative appraisal of their job or job experiences would be more likely to engage deviance in workplace. Many studies have proven that some dissatisfied employees and those who do not like their work environment even if they sometimes react on it (Hackman \& Oldham, 1976).

One of the main factors that enhance efficiency and success of employees in the workplace is work satisfaction, which is more dependent on human resource management in the organization. (Crossman \& AbouZaki, 2003). Based on the research of Ladebo, Awotunde, and AbdulSalaam-Saghir (2008) the role of appropriate environment of the workplace and respect to the employees' impact on increasing employees 'satisfaction and organizational productivity. On the other hand, dissatisfied respondents tend to cite extrinsic factors such as supervision, pay, company policies and working condition. Moreover, research has suggested that job dissatisfaction is related to measures of deviant behaviors (Bennett \& Robinson, 2000). Likewise, Judge et al. (2001) obtained a negative correlation between work satisfaction and workplace deviance in their studies.

Yperen in (1996) described that employees who encounter unfairness in the organization become displeased worker, that absenteeism among displeased worker is higher than normal workers. In a similar research of Schwarzwald, Koslowsky, and Shalit (1992) those employees expecting to promoted by organization but ignored has a tendency to absent or engaging deviance. Kulas, McInnerney, DeMuth, and Jadwinski (2007) perceived that the negative relationship between deviance and work satisfaction. They also highlighted, lack of satisfaction in workplace is one of the main motivations for an employee to dysfunction or steal at work place.

According to Judge, Scott, and Ilies (2006) work satisfaction and deviance in the organization are negatively related to each other. Based on Tuna, Ghazzawi, Yesiltas, Tuna, and Arslan (2016) findings suggest that there is a negative correlation between work satisfaction and organizational deviant work behaviors. Furthermore employees ' satisfaction leads to workplace harmony and brings employees closer to the purpose of the organization. Results from the research of Abbasi et al. (2020) show high, and negative impact of job satisfaction on workplace deviance. Hence, the reviews of the above literature that highlight and rely on social exchange theory, work satisfaction have an impact on workplace deviance; therefore, the following hypothesis are proposed;

Hypothesis 2: There is a negative relationship between work satisfaction and workplace deviance.

\subsection{Trust in Management and Workplace Deviance}

In order to understand the relationship between trust in management and employee performance, it is important to consider how employees can be vulnerable to management, and how vulnerability relates to performance. Vulnerability can derive from a number of sources. It is important to recognize that an employee can become vulnerable both through active behavior and through passive behavior, or by opting not to engage in self-protective behavior. For instance, sharing information with a manager that is potentially damaging to the employee is an example of an active behavior that actually puts the employee at risk. If the manager uses the information, either intentionally or unintentionally, in a way that damages the employee's interests, the outcome for the employee is negative. Propose that such negative outcomes will lead the employee to reevaluate the manager's trustworthiness, and subsequently be less willing to be vulnerable to the manager at a later point in time (Mayer et al., 1995).

Sharing sensitive information is one example of an active behavior that puts the employee at risk. However, not all behavior that puts the employee at risk is active. For example, monitoring a manager who has a significant impact on an employee's important outcomes is a means of reducing the risk associated with the manager's influence over the outcomes. If the manager begins to take actions that could damage the employee's interests, by closely monitoring, the employee can more quickly take action to lessen the negative effects of the manager's influence. Another related action which is more active and which reduces the employee's risk is taking actions to "cover one's back." If an employee is unwilling to be vulnerable to a given member of management, the employee will proactively attempt to gather information and present an image to influential others in the organization that the employee's actions are justified and that his or her performance is satisfactory (Mayer \& Gavin, 2005).

One of the significant organizational related factor judging the expectancy of members involvement in doing misbehave in work environment is trust in management. Trust in management mentions the level of employee's trust to the management of an organization at various stages of its chain of command, not essentially only top manager. Trust in management has been discussed as determinant of workplace deviant (M. Alias, Rasdi, Ismail, 
\& Samah, 2013). Researchers shown assert trust in organization and increase loyalty between employees contribute organization reach their goal and achieve vision (Liao, Joshi, \& Chuang, 2004). However, Absence of trust causes rising anger and disgust in member of organization consequently deviant behavior increase as well (Too \& Harvey, 2012). Similar study also proved a negative relationship among trust in high-ranking management and abnormal behavior in work environment. In conclude, according to above discussion, trust in management is a noticeable alternative that influencing support personnel's involve towards deviant behavior.

One of the recent research findings showed that leadership in organization directly affected of trust of employees to managers and positively and significantly influenced organizational learning and efficiency of employees (E.-J. Kim \& Park, 2019). Hence, the reviews of the above literature that highlight and rely on social exchange theory, trust in management have an impact on workplace deviance; therefore, the following hypothesis are proposed;

Hypothesis 3: There is a negative relationship between trust in management and workplace deviance.

\subsection{Research Framework}

As it is illustrated in Figure 1.1 the relationship between the trust in management, work satisfaction and workplace deviance is shown. This framework is designed according to the current literature review that work satisfaction is the mediator and workplace deviance is the dependent variable.

H3

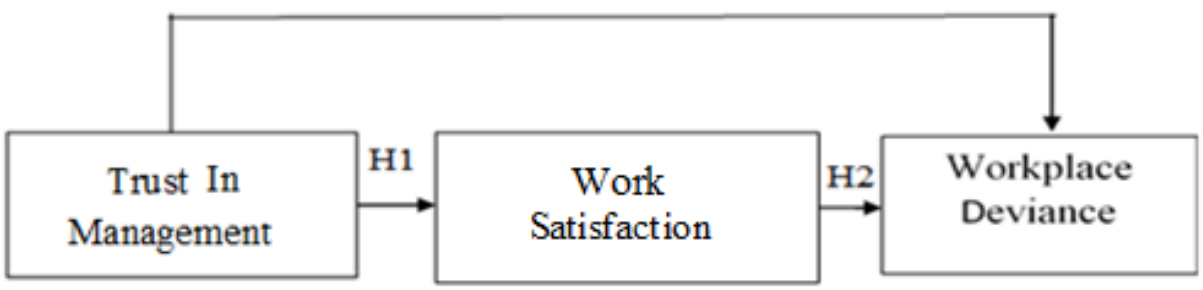

Figure 1.1 Conceptual Framework

\section{Methods \\ 3.1 Sample Procedures}

In this research Simple Random Sampling was used. The target population of this research is selected small and medium enterprises (SMEs) employees in Malaysia. There are approximately 21,000 SMEs companies in Malaysia. The researchers emailed 150 questionnaire and 115 responses were received. This research is conducted among all employees who work in SMEs Malaysia. This study focused on deviance in the organization that might be affected by trust in management and work satisfaction. The independent variable for this research would be trust in management. The mediating variable would be work satisfaction and the dependent variable is workplace deviance. The questionnaire of this study is prepared based on prior research on trust in management, job satisfaction and workplace deviance. The questionnaires were distributed randomly to the employees from different industries in Malaysia. From the 150 online questionnaires, 115 responses were received.

\subsection{Measures}

Based on the review of workplace deviance, a total of 16 questions were used in this research., five questions were adopted from (Brayfield \& Rothe, 1951), and 6 questions were taken from Jie Guo Mccadle (1998) with some modification. Five question also taken from Bella L. Calperin (2002). Basically, the questionnaire was divided into two group sections: demographic section and main section. The questionnaire was written in English. Section A focused on the demographic profile of the respondents. This section covered the background of company, year of establishment, number of employees, background of respondents including sex, age, marital status, race, education level, educational background, years of working experience, and length of service with the current organization, position, and year of last promotion in the organization. Section B consisted of three parts that include 16 questions. This part measures trust in management, work satisfaction and workplace deviance. This section is divided into three parts based on the conceptual framework.

Section B1: Five questions of trust in management.

Section B2: Five questions on work satisfaction.

Section B3: Six questions on workplace deviance.

The Likert scale was used in this research and asked respondents to rate each statement from strongly disagree to strongly agree. Likert scale was used in this study to generate statistical measurement of the impact of organizational justice and job satisfaction on workplace deviance. According to Sekaran (2009), the Likert scale is commonly used in the questionnaire survey. The responses over a number of items tapping a particular concept 
or variable can be analyzed item by item, but it is also possible to calculate a total or summated score for each respondent by summing across items. The summated approach is widely used, and therefore the Likert scale is also referred to as a smoothed scale.

4 Results

This study strive to find predictors of workplace deviance also investigated the mediate of work satisfaction among trust in management and workplace deviance in organization between Malaysian employees. In this section will presents the reporting of the results of this exploratory study arranged in context to the research objective from the questionnaire that following themes were found. In this section will explain the results of the data analysis. The ultimate goal is to declare the findings of the study.

\subsection{Frequency Analysis}

Displaying Frequency tables for variables can help readers understand how many participants are in each level of a variable and how much missing data of various types exists (Leech, Barrett, \& Morgan, 2008). Age: From our result It can be seen that huge portion of the respondents are between ages of 25 to 40 , which comprise of $73 \%$ of the total population with an obvious difference with the second portion of respondent $(40-55)$ with only $17 \%$ of whole respondents. Educational level demonstrates participants are mainly Master holders with allocate $58 \%$ of the pie chart and then Bachelor Degree holders at 37\% whole pie. However, Diploma holders with only 3\% are of the consideration. Positions: participants are mainly Engineer/Executive (43\%), Manager (20\%), Section Head, Assistant Manager and CEO/General Manager comprise 18\%, 17\%, 2\% of respectively. Number of employees: The pie chart show number of employee's participant in this research questionnaire with a total number of 115 respondent. Overall, it can be seen that respondent is included from small, medium and large company size. Most of the participant were from medium company size with employee's rang of $10-100$ comprise $37 \%$ of the pie chart.

\subsection{Exploratory Factor Analysis for Dependent}

The assumption of independent sampling was met. The assumption of normality, linear relationships between pair of variables, and the variables being correlated at a moderate level (as it is presented in below the KMO's measure of adequacy for both dependent and mediator are greater than 0.7 and Bartlett's Test of Sphericity for both is significant) were checked. Items of each construct have been checked each at a time. Principal component was selected considerd as the extraction method. In terms of rotation, Direct Oblimin was chosen and finally items with loading less than 0.6 were omitted from each construct. Tables $1.1,1.2$ and 1.3 displays the items and factor loadings for the related factors, with loading less than 0.6 omitted to improve clarity.

Table 1.1: Factor Analysis

\begin{tabular}{|l|l|l|}
\hline \multicolumn{3}{|c|}{ Trust in Management } \\
\hline Kaiser-Meyer-Olkin Measure of Sampling Adequacy. & .860 \\
\hline Bartlett's Test of Sphericity & \multicolumn{2}{l|}{504.280 (sign0.000 def=10) } \\
\hline Eigenvalue: 3.611 & \multicolumn{1}{|l|}{ Cumulative Variance: $72.213 \%$} \\
\hline \multicolumn{1}{|c|}{ Factor/item } & Factor loading & Communalities \\
\hline 1.I have the sufficient support from my top manager. & .942 & .888 \\
\hline 2.My top manager understands my problems and needs. & .937 & .877 \\
\hline $\begin{array}{l}\text { 3.My manager clarifies decision and provides additional } \\
\text { information when requested by employees. }\end{array}$ & .943 & .889 \\
\hline $\begin{array}{l}\text { 4.When decision are made about my job, my manager } \\
\text { shows concern for my right as an employee }\end{array}$ & .928 & .861 \\
\hline Internal consistency reliability (Cronbach's alpha) & & .901 \\
\hline
\end{tabular}


Table 1.2: Factor Analysis

\begin{tabular}{|c|c|c|}
\hline \multicolumn{3}{|l|}{ Work Satisfaction } \\
\hline Kaiser-Meyer-Olkin Measure of Sampling Adequacy. & \multicolumn{2}{|l|}{.906} \\
\hline Bartlett's Test of Sphericity & \multicolumn{2}{|c|}{$620.485(\operatorname{sign} 0.000 \mathrm{def}=10)$} \\
\hline Eigenvalue: 4.222 & \multicolumn{2}{|c|}{ Cumulative Variance: $84.443 \%$} \\
\hline Factor/item & Factor loading & Communalities \\
\hline 1.I am very satisfied with my Work. & .935 & .875 \\
\hline 2.Most days I am enthusiastic about my Work. & .929 & .863 \\
\hline 3.I like my Work better than the average worker does. & .944 & .890 \\
\hline 4.I find real enjoyment in my Work. & .944 & .891 \\
\hline 5.I definitely dislike my Work (R). & .838 & .703 \\
\hline Internal consistency reliability (Cronbach's alpha) & \multicolumn{2}{|c|}{.953} \\
\hline
\end{tabular}

Table 1.3: Factor Analysis

\begin{tabular}{|l|l|l|}
\hline \multicolumn{2}{|c|}{ Workplace Deviance } & 0.812 \\
\hline Kaiser-Meyer-Olkin Measure of Sampling Adequacy. & 366.514 (sig 0.000 df =15) \\
\hline Bartlett's Test of Sphericity & Cumulative Variance: 59.289\% & Communalities \\
\hline Eigenvalue: 6.050 & Factor loading & .731 \\
\hline Factor/item & .709 & .748 \\
\hline D3.I neglect to follow my manager's instructions. & .865 & .816 \\
\hline $\begin{array}{l}\text { D4.Spend too much time fantasizing or daydreaming instead } \\
\text { of working. }\end{array}$ & .903 & .744 \\
\hline D5.I Intentionally worked slower than I could. & .862 & \\
\hline D6.I take longer break than is acceptable at work. & & .710 \\
\hline Internal consistency reliability (Cronbach's alpha) & & \\
\hline
\end{tabular}

Table 1.4 shows the Pearson Correlation test for hypothesis 1 and. Significant positive correlations between trust in management and work satisfaction at $<0.001$ has been found. Therefore, hypothesis 1 is supported. Work satisfaction $(\mathrm{r}=0.868)$ is significantly correlated as well. Accordingly, independent variables show significant correlation with work satisfaction while correlations are positive. Finally, hypothesis is supported. This means as trust in management increases, work satisfaction also increases and such variations are in same direction.

Table 1.4: Correlation between Work Satisfaction and Trust in Management dimensions Parametric Correlations -Pearson $\quad$ Significant
Correlation ' $r$ '

\begin{tabular}{lll}
\hline Trust in Management & .868 & 0.000 \\
\hline
\end{tabular}

4.3 Work Satisfaction as Dependent Variable and Trust in management as Predictor

Multiple Regressions was conducted to determine the best linear combination of Independent variables of this study trust in management for predicting work satisfaction as mediator. The means, standard deviations, and inter- 
correlations can be found in Tables 1.5 . This combination of variables significantly predicted work satisfaction, $\mathrm{F}$ $(3,111)=174.371, p<.001$, with two variables significantly contributing to the prediction. The beta weights, presented in table 1.5 suggest that contribute to predicting work satisfaction, whereas is trust in management considered as significant predictor. The adjusted $\mathrm{R}$ squared value was 0.820 . This indicates that $82 \%$ of the variance in work satisfaction was explained by the model. According to Cohen (1988), this is a large effect.

Table 1.5: Multiple Regression of Work Satisfaction on Trust in Management $(\mathrm{N}=115)$

\begin{tabular}{rrrrr}
\hline Variables & $\mathrm{B}$ & $\mathrm{Beta}$ & $\mathrm{t}$ & $\mathrm{P}($ Sig.) \\
\hline (Constant) & -1.862 & & -1.947 & .054 \\
Trust in management & .552 & .444 & 5.061 & .000 \\
& $\mathrm{R}=.908$ & & & \\
& $\mathrm{R}^{2}=.825$ & & & \\
Adjusted $\quad \mathrm{R}^{2}=.820$ & & & & \\
\hline
\end{tabular}

Note: $F(3,111)=174.371$

Table 1.6 shown that the Pearson Correlation test for hypothesis 3 is significant. There is a negative correlation between work satisfaction and workplace deviance at $<0.001$. Therefore, hypothesis 3 is supported $(r=-0.399)$. This means as work satisfaction increases, workplace deviance reduces and such variations are not in the same direction.

Table 1.6: Correlation between Workplace Deviance and Work Satisfaction

\begin{tabular}{lcc}
\hline & $\begin{array}{c}\text { Parametric Correlations - } \\
\text { Pearson Correlation 'r' }\end{array}$ & Significant \\
\hline Work satisfaction & -.399 & 0.000 \\
\hline
\end{tabular}

4.4 Workplace Deviance as Dependent variable and Work Satisfaction as Predictor

Multiple regression was conducted to determine the best linear combination of two factors of this study including work Satisfaction for predicting workplace deviance. This variable significantly predicted workplace deviance, $\mathrm{F}$ $(1,113)=21.370, \mathrm{p}<.001$. The beta weight, presented in Table 1.7 suggest that work satisfaction contributes negatively (Beta $=-0.399$ ) to predicting workplace deviance. The adjusted $\mathrm{R}$ squared value was .152 . This indicates that 15.2 percent of the variance in workplace deviance was explained by the model.

Table 1.7: Simultaneous multiple regression of worklace deviance on work satisfaction

\begin{tabular}{rcccc}
\hline Variables & $\mathrm{B}$ & $\mathrm{Beta}$ & $\mathrm{T}$ & $\mathrm{P}(\mathrm{Sig})$. \\
\hline (Constant) & 12.208 & & 12.703 & .000 \\
1. Job Satisfaction & -.258 & $-.399 * * *$ & -4.623 & .000 \\
$\mathrm{R}=.399$ & & & & \\
$\mathrm{R} 2=.159$ & & & \\
Adjusted $\quad \mathrm{R} 2=.152$ & & & & \\
\hline
\end{tabular}

Note: $\mathrm{F}(1,113)=21.370, * * * \mathrm{p}<.001$

5 Conclusion

This study's intention is expand literature review by showing support for the predictors of trust in management on workplace deviance. This study has a number of proper implications for organizational strategies in order the prevention of unexpected organization behaviors. Deviance conduct contains significant cost for organizations that some of these costs are not compensated by the companies. Follow organization's policies and instructions is essential for each company to remain survival in this competition industry.

Employees' neglect to follow the accepted norms and rules may put in danger the organization's whole effectiveness and jeopardize company investment. Such as those employee misbehavior, can say: neglecting to follow superior's instructions, deliberate employee slowdown, lateness, negligible theft, and acting rudely with colleagues, can be very harmful to the organizational well-being. However, pushing employee and monitor them persistently may in some cases be undesirable for organizations. Several conclusions obtained from the hypothesis include: a) Trust in management have positive effects on work satisfaction and negative effect on workplace deviance. b) Trust in management and work satisfaction are predictors of workplace deviance. 
This research gives some recommendation to mangers for increasing of trust in organization that is salient for each construct and allows the management of organizations to take appropriate actions to improve conditions at the workplace. Another advantage of increasing trust in organization is prevent deviance in the workplace, the management must create environment that employee perceive enough care and support.

\section{References}

Abbasi, A., Baradari, F., Sheghariji, H., \& Shahreki, J. (2020). Impact of Organizational Justice on Workplace Deviance with Mediating Effect of Job Satisfaction in SMEs of Malaysia. European Journal of Business and Management, 12(17), 11, 52-63.

Abbasi, A., \& Wan Ismail, W. K. (2018). Individual Predictors of Workplace Deviance with Mediating Effect of Job Satisfaction. European Journal of Business and Management, 10(14), 1-6.

Alias, \& Rasdi, R. (2015). Organizational Predictors of Workplace Deviance among Support Staff. ProcediaSocial and Behavioral Sciences, 172, 126-133.

Alias, M., Rasdi, R. M., Ismail, M., \& Samah, B. A. (2013). Predictors of workplace deviant behaviour: HRD agenda for Malaysian support personnel. European Journal of Training and Development, 37(2), 161182.

Allen, D. G., Shore, L. M., \& Griffeth, R. W. (2003). The role of perceived organizational support and supportive human resource practices in the turnover process. Journal of management, 29(1), 99-118.

Bennett, R. J., \& Robinson, S. L. (2000). Development of a measure of workplace deviance. Journal of applied psychology, 85(3), 349.

Bennett, R. J., \& Robinson, S. L. (2003). The past, present, and future of workplace deviance research.

Brayfield, A. H., \& Rothe, H. F. (1951). An index of job satisfaction. Journal of Applied Psychology, 35(5), 307.

Colquitt, J. A., Conlon, D. E., Wesson, M. J., Porter, C. O., \& Ng, K. Y. (2001). Justice at the millennium: a metaanalytic review of 25 years of organizational justice research. Journal of Applied Psychology, 86(3), 425.

Cranny, C., Smith, P. C., \& Stone, E. (1992). Job satisfaction: How people feel about theirjobs.

Crossman, A., \& Abou-Zaki, B. (2003). Job satisfaction and employee performance of Lebanese banking staff. Journal of Managerial Psychology, 18(4), 368-376.

Dormann, C., \& Zapf, D. (2001). Job satisfaction: a meta-analysis of stabilities. Journal of organizational behavior, 22(5), 483-504.

Everton, W. J., Jolton, J. A., \& Mastrangelo, P. M. (2007). Be nice and fair or else: understanding reasons for employees' deviant behaviors. Journal of Management Development, 26(2), 117-131.

Ganzach, Y. (1998). Intelligence and job satisfaction. Academy of management journal, 41(5), 526-539.

Gill, A. S. (2008). The role of trust in employee-manager relationship. International Journal of Contemporary Hospitality Management, 20(1), 98-103.

Hackman, J. R., \& Oldham, G. R. (1976). Motivation through the design of work: Test of a theory. Organizational behavior and human performance, 16(2), 250-279.

Hollinger, R. C., \& Clark, J. P. (1983). Deterrence in the workplace: Perceived certainty, perceived severity, and employee theft. Social Forces, 62(2), 398-418.

Judge, T. A., Scott, B. A., \& Ilies, R. (2006). Hostility, job attitudes, and workplace deviance: test of a multilevel model. Journal of applied psychology, 91(1), 126.

Judge, T. A., Thoresen, C. J., Bono, J. E., \& Patton, G. K. (2001). The job satisfaction-job performance relationship: A qualitative and quantitative review. Psychological bulletin, 127(3), 376.

Kim, E.-J., \& Park, S. (2019). The role of transformational leadership in citizenship behavior. International journal of manpower.

Kim, S. J., \& Chung, E. K. (2019). The effect of organizational justice as perceived by occupational drivers on traffic accidents: Mediating effects of job satisfaction. Journal of safety research, 68, 27-32.

Kulas, J. T., McInnerney, J. E., DeMuth, R. F., \& Jadwinski, V. (2007). Employee satisfaction and theft: Testing climate perceptions as a mediator. The Journal of Psychology, 141(4), 389-402.

Ladebo, O. J., Awotunde, J. M., \& AbdulSalaam-Saghir, P. (2008). Coworkers' and supervisor interactional justice: Correlates of extension personnel's job satisfaction, distress, and aggressive behavior. Journal of Behavioral and Applied Management, 9(2), 1930-0158.

Lee, Y.-D., \& Chang, H.-M. (2008). Relations between Team Work and Innovation in Organizations and the Job Satisfaction of Employees: A Factor Analytic Study. International Journal of Management, 25(4).

Leech, N. L., Barrett, K. C., \& Morgan, G. A. (2008). SPSS for Intermediate Statistics: Use and Interpretation (3rd ed.). New York: Lawrence Erlbaum Associate - Taylor and Francis Group, LLC.

Liao, H., Joshi, A., \& Chuang, A. (2004). Sticking Out Like a Sore Thumb: Employee Dissimilarity and Deviance at Work*. Personnel Psychology, 57(4), 969-1000.

Mayer, R. C., Davis, J. H., \& Schoorman, F. D. (1995). An integrative model of organizational trust. Academy of management review, 20(3), 709-734. 
Mayer, R. C., \& Gavin, M. B. (2005). Trust in management and performance: who minds the shop while the employees watch the boss? Academy of management journal, 48(5), 874-888.

Pierce, H. R., \& Maurer, T. J. (2009). Linking employee development activity, social exchange and organizational citizenship behavior. International Journal of Training and Development, 13(3), 139-147.

Qi, L., Liu, B., \& Mao, K. (2020). Spare the rod and spoil the child? A study on employee workplace deviant behavior. Nankai Business Review International.

Schwarzwald, J., Koslowsky, M., \& Shalit, B. (1992). A field study of employees' attitudes and behaviors after promotion decisions. Journal of applied psychology, 77(4), 511.

Shore, L. M., Chung-Herrera, B. G., Dean, M. A., Ehrhart, K. H., Jung, D. I., Randel, A. E., \& Singh, G. (2009). Diversity in organizations: Where are we now and where are we going? Human resource management review, 19(2), 117-133.

Too, L., \& Harvey, M. (2012). "TOXIC" workplaces: the negative interface between the physical and social environments. Journal of Corporate Real Estate, 14(3), 171-181.

Tuna, M., Ghazzawi, I., Yesiltas, M., Tuna, A. A., \& Arslan, S. (2016). The effects of the perceived external prestige of the organization on employee deviant workplace behavior. International Journal of Contemporary Hospitality Management.

Wharton, A. S., Rotolo, T., \& Bird, S. R. (2000). Social context at work: A multilevel analysis of job satisfaction. Paper presented at the Sociological Forum. 